\title{
Glyphosate adsorption by Eucalyptus camaldulensis bark-mediated char and optimization through response surface modeling
}

\author{
Kamalesh Sen $^{1} \cdot$ Jayanta Kumar Datta ${ }^{1} \cdot$ Naba Kumar Mondal $^{1}$
}

Received: 24 March 2019 / Accepted: 4 September 2019 / Published online: 28 September 2019

(c) The Author(s) 2019

\begin{abstract}
In this study, orthophosphoric acid-modified activated char was prepared from Eucalyptus camaldulensis bark (EBAC), and used for removing traces of [ $N$-(phosphonomethyl)glycine] (glyphosate) herbicide from aqueous solution. The adsorption capacity was characterized by zero-point-charge $\mathrm{pH}$, surface analysis, and Fourier transform infrared spectroscopy. Batch mode experiments were conducted to observe the effects of selected variables, namely dose, contact time, $\mathrm{pH}$, temperature, and initial concentration, on adsorption capacity. Langmuir, Freundlich, Temkin, and Dubinin-Radushkevich isotherm models were generated to describe the mechanisms involved in the multilayer adsorption process. The results show that high temperature enhanced the adsorption capacity of EBAC, with a temperature of $373 \mathrm{~K}$ yielding adsorption capacity $\left(q_{\mathrm{max}}\right)$ and Freundlich parameter $\left(K_{\mathrm{F}}\right)$ of $66.76 \mathrm{mg} \mathrm{g}^{-1}$ and $9.64\left(\mathrm{mg} \mathrm{g}^{-1}\right)\left(\mathrm{L} \mathrm{mg}^{-1}\right)^{-n}$, respectively. The thermodynamics study revealed entropy and enthalpy of $-5281.3 \mathrm{~J} \mathrm{~mol}^{-1}$ and $-20.416 \mathrm{~J} \mathrm{~mol}^{-1}$, respectively. Finally, glyphosate adsorption was optimized by the Box-Behnken model, and optimal conditions were recorded as initial concentration of $20.28 \mathrm{mg} \mathrm{L}^{-1}$, $\mathrm{pH} 10.18$, adsorbent dose of $199.92 \mathrm{mg} / 50 \mathrm{~mL}$, temperature of $303.23 \mathrm{~K}$, and contact time of $78.42 \mathrm{~min}$, with removal efficiency of $98 \%$. Therefore, it can be suggested that EBAC could be used as an efficient, low-cost adsorbent for removal of glyphosate from aqueous solutions.
\end{abstract}

Keywords Glyphosate $\cdot$ Eucalyptus camaldulensis bark $\cdot$ Box-Behnken $\cdot$ Isotherms $\cdot$ Kinetics $\cdot$ Thermodynamics

\section{Introduction}

Contamination of agricultural fields by the release of toxic chemicals remains a significant problem in the agricultural sector (Abbasi et al. 2014). The extensive use of chemical fertilizers can reduce soil fertility and microbial diversity (Trivedi et al. 2016; Ermakova et al. 2010). Various studies have reported a tremendous impact of different pesticides, including glyphosate, napropamide, metam sodium, methyl bromide, and copper, in terms of changes to soil microbial community composition and ecosystems and reduced crop

Electronic supplementary material The online version of this article (https://doi.org/10.1007/s13201-019-1036-3) contains supplementary material, which is available to authorized users.

Naba Kumar Mondal

nkmenvbu@gmail.com

Environmental Chemistry Laboratory, Department of Environmental Science, The University of Burdwan, Bardhaman, West Bengal, India tolerance (Lancaster et al. 2010; Cycon et al. 2013; Locke et al. 2008; Berg et al. 2012; Cosgrove et al. 2019).

Glyphosate $\left(\mathrm{C}_{3} \mathrm{H}_{8} \mathrm{NO}_{5} \mathrm{P}\right)$ is an aminophosphonic analog of the natural amino acid glycine and, like all amino acids, exists in different ionic states depending on $\mathrm{pH}$, showing zwitterionic form with a phosphonate proton by delocalization of the amino nitrogen (Borggaard and Gimsing 2008). Its solubility in water is $1.01 \mathrm{~g} / 100 \mathrm{~mL}\left(20^{\circ} \mathrm{C}\right)$, with molar mass of $169.1 \mathrm{~g} \mathrm{~mol}^{-1}$. At different $\mathrm{pH}$, possible acid dissociate constants are as $\mathrm{pK}_{\mathrm{a} 1}=2.32$ (carboxylate), $\mathrm{pK}_{\mathrm{a} 2}=5.86$ (phosphonate), and $\mathrm{pK}_{\mathrm{a} 3}=10.86$ (amino), (Villamar-Ayala et al. 2019; Mayakaduwa et al. 2016).<smiles>O=C(O)CNCP(=O)(O)O</smiles>

Glyphosate 
The current global demand for glyphosate has been reported at 500,000 metric tons per year, with a total market value of more than $\$ 5$ billion reported for 2011 to 2016 (Bai and Ogbourne 2016), and a predicted increase to as much as $\$ 10-15$ billion within the near future (Global Industry Analyst Press 2011; Poiger et al. 2016).

Glyphosate [ $N$-(phosphonomethyl)-glycine] is an organophosphate herbicide, widely used for controlling various sedges, plants, unwanted vegetation, weeds, and grasses (Guo et al. 2005; He et al. 2019). Water contamination (ground and surface) through irrigation of crop fields, leaks, and discharge from industry has been reported (Hu et al. 2011; Cosgrove et al. 2019). The toxicity of phosphonates may have a significant impact on human health; for example, it was found to have a major effect as an endocrine disruptor in human placental tissue (Richard et al. 2005). These concerns have led to the demand for new and sustainable water remediation methods.

Various conventional methods for glyphosate removal include reverse osmosis, precipitation, coagulation, chemical degradation, chemical oxidation, and adsorption. However, these techniques all have a major limitation in that they produce secondary pollutants, with the exception of adsorption processes (Rajasulochana and Preethy 2016). Adsorption is a technique used for wastewater treatment, which involves the interaction of adsorbate and adsorbent via physisorption and chemisorption (Herath et al. 2016; Mayakaduwa et al. 2016). The particular adsorption mechanisms are determined from kinetic, isotherm, and thermodynamic models.

Glyphosate has different functional groups, giving rise to donor groups including phosphonate, amino, and hydroxyl in aqueous medium, which can bind to the adsorbent surface during the adsorption process (Jensen et al. 2009). Previous studies have investigated glyphosate adsorption by various materials, including waste residue (Hu et al. 2011), woody char (Mayakaduwa et al. 2016), resin (Chen et al. 2016), $\mathrm{MnFe}_{2} \mathrm{O}_{4}$-graphene hybrid composite (Yamaguchi et al. 2016), biochar-supported zerovalent iron (Jiang et al. 2018), Zr-MOF (Yang et al. 2018), graphene oxide/ $\mathrm{TiO}_{2}$ nanocomposite (Hosseini and Toosi 2019), and forest soil (Sen et al. 2017). However, no studies have investigated eucalyptus bark char for glyphosate separation.

The ability to enhance adsorption capacity through the modification of adsorbents (e.g., acid/alkaline-modified, oxide-activated, impregnated, doped absorbents) has expanded the potential for adsorption processes, as modified adsorbents possess improved mechanisms for the uptake of pollutants compared with conventional materials (Jiuhui 2008; Akhtar et al. 2007). Nevertheless, studies are needed to observe the uptake capacity of various adsorbents. Bioadsorbents that have been previously applied (e.g., rice husk ash, prawn shell-activated carbon, sugarcane bagasse, mango seed powder, sawdust, pine needles, eucalyptus bark) have shown varying adsorption capacity based on the different adsorbates (Sud et al. 2008; Salleh et al. 2011; Roy and Mondal 2019; Ghosh and Mondal 2019). Therefore, there is an urgent need to develop adsorbents with significantly increased absorption ability.

Biochar has emerged as a promising material for bioenergy utilization, pollution minimization, and biomaterial waste management, and can be manufactured economically at very low cost. Chemical modification of organic-containing substances through activated carbon production has been shown to increase the uptake capacity for several pollutants (Mayakaduwa et al. 2016; Djilani et al. 2015). Biochar has been found to be a remarkable adsorbent for wastewater treatment, with outstanding potential for pesticide adsorption (Liu et al. 2016).

Response surface methodology (RSM) is a statistical optimization technique that has been used to predict adsorption involving operating variables such as $\mathrm{pH}$, contact time, and temperature (Sadafa et al. 2015; Goel et al. 2006). Many optimization processes have been introduced previously, including maximum central composite, Doehlert, and Box-Behnken design. However, in most cases, the Box-Behnken has achieved perfectly three levels optimized per factor with fewer experimental data points, and output efficiency has been shown to fit extremely well as compared with experimental results (Ferreira et al. 2007; AlMusawi et al. 2019). The operating variables were assessed by analysis of variance (ANOVA), and various variables can be understood from the 3D surface plot. The model performance is assessed based on the $F$ value (Chattoraj et al. 2016; Sen et al. 2017; Mondal et al. 2019a).

The present study aims to prepare an activated char adsorbent for the removal of glyphosate from aqueous solution through batch mode. An adsorption equilibrium study is carried out by isotherm modeling, using Freundlich, Langmuir, Dubinin-Radushkevich (D-R), and Temkin isotherms. The kinetics of the adsorption reaction is modeled by pseudosecond-order and intraparticle diffusion. Gibbs-Helmholtz equations are used to calculate the adsorption free energy. In addition, the optimization of glyphosate adsorption through response surface design is evaluated by the experimental data.

\section{Materials and methods}

\section{Chemicals and reagents}

Glyphosate (PESTANAL ${ }^{\circledR}$, analytical standard, CAS number 1071-83-6; molecular weight $169.07 \mathrm{~g} \mathrm{~mol}^{-1}$ ) purchased from Sigma-Aldrich (St. Louis, MO, USA), 2,2-dihydroxyindane-1,3-dione (ninhydrin, Sigma-Aldrich), and sodium 
molybdate (Merck India Ltd.) were used for glyphosate analysis, and all studies were initiated with distilled water.

\section{Adsorbent preparation}

Eucalyptus bark was collected from the Chandur forest $\left(22.9103^{\circ} \mathrm{N}, 87.7683^{\circ} \mathrm{E}\right)$, Arambagh, West Bengal, India. To separate the impurities, the bark was first washed repeatedly with tap water followed by distilled water, after which the bark was cut into pieces manually and then placed in a muffle furnace at $300{ }^{\circ} \mathrm{C}$ for $2 \mathrm{~h}$. The charred eucalyptus bark was placed in a brown container with $6(\mathrm{~N})$ orthophosphoric acid overnight at $60^{\circ} \mathrm{C}\left(\mathrm{EBA}: \mathrm{H}_{3} \mathrm{PO}_{4}=1: 3\right)$, and then neutralization was made with $0.1(\mathrm{~N}) \mathrm{NaOH}$. Subsequently, the substances were washed with $20 \%$ methanol and deionized water, and the adsorbent was then dried in a hot oven and stored in an airtight container for further adsorption study.

\section{Eucalyptus camaldulensis bark-activated char (EBAC) characterization and methodology}

Characterization was performed using a quantitative elemental analyzer (vario MAX CN, Germany), and $\mathrm{pH}$ and electrical conductivity (EC), with a sample ratio of 1:10 (W/V), were measured using a digital $\mathrm{pH} / \mathrm{EC}$ meter (Eutech PC-700). Moisture content, volatile matter, and ash and carbon content (organic matter) were determined using standard methods (Yakout and Sharaf El-Deen 2016). Pore size distribution was assessed by the Barrett-Joyner-Halenda (BJH) method. The Brunauer-Emmett-Teller (BET) surface area was determined using a surface analyzer (Quantachrome Nova 2200C), where nitrogen gas was used. The infrared spectra of the EBAC adsorbent, before and after glyphosate loading, were analyzed using Fourier transform infrared (FTIR) spectroscopy (PerkinElmer RX1) in the range of $400-4000 \mathrm{~cm}^{-1}$. Lastly, the chosen batch adsorption study was conducted using a thermostatic magnetic stirring system (Tarsons, digital-MC02).

The zero-point-charge $\mathrm{pH}$ value $\left(\mathrm{pH}_{\mathrm{zpc}}\right)$ was estimated using $0.1(\mathrm{M}) \mathrm{KNO}_{3}$ solution. In each $100 \mathrm{~mL}$ conical flasks, $50 \mathrm{~mL}$ of $0.1(\mathrm{M}) \mathrm{KNO}_{3}$ solution was taken with prpoper adjustment of $\mathrm{pH}(2-12)$. Then place within several containers of $1.0 \mathrm{~g}$ dosage, stay longer in vibration mode up to $48 \mathrm{~h}$. Measured the final $\mathrm{pH}$, and $\mathrm{pH}$ was differentiated between initial and final. The $\mathrm{pH}_{\mathrm{zpc}}$ was calculated by plotting the difference between the final $\mathrm{pH}$ and initial $\mathrm{pH}$ (Bourikas et al. 2003).

\section{Biosorption experiments}

The prepared glyphosate solution $\left(5-50 \mathrm{mg} \mathrm{L}^{-1}\right)$ was subjected to experiments in order to determine the influence of EBAC dose (0.1-2 g), $\mathrm{pH}(2-12)$, contact time (5-120 min), and temperature $\left(30-100{ }^{\circ} \mathrm{C}\right)$.
The glyphosate adsorption percentage and capacity were calculated using the following mathematical equations (Tan and Hameed 2010; Mondal et al. 2019b):

Adsorption $_{\text {glyphosate }}(\%)=\frac{\left(C_{\text {initial }}-C_{\text {final }}\right) \times 100}{C_{\text {initial }}}$

$q_{\text {capacity }(\mathrm{mg} / \mathrm{g})}=\frac{\left(C_{\text {initial }}-C_{\text {final }}\right) \times V}{m_{\text {dose }}}$

where $C_{\text {initial }}$ is the initial glyphosate concentration $\left(\mathrm{mg} \mathrm{L}^{-1}\right)$, $\mathrm{C}_{\text {final }}$ is the equilibrium concentration, which is the remaining concentration after adsorption, $V$ is the amount of solution (mL), and $m_{\text {dose }}$ is the EBAC mass $(\mathrm{g})$ involved in glyphosate removal. The measurement of glyphosate concentrations was performed using spectrometric (PerkinElmer K-35) detection of absorbance at $540 \mathrm{~nm}$ (Bhaskara and Nagaraja 2006).

\section{Response surface methodology}

\section{Mathematical modeling}

Mathematical modeling was applied using the response surface methodology (RSM) technique via Box-Behnken design, with the independent predictor variable of EBAC dose, temperature, contact time, $\mathrm{pH}$, and glyphosate concentration, and each parameter taken as variables (Montgomery2001). Models were generated using Design-Expert software (version 7.1, Stat-Ease Inc., Minneapolis, MN, USA). The functionalized parameters are represented by the following optimization equation:

$y=f\left(X_{1}, X_{2}, X_{3} \ldots X_{k}\right)+\varepsilon$

where $f$ is the real response function and $\varepsilon$ is the residual factor associated with the experiments. The surface is represented by the terms $f\left(X_{i}, X_{j}\right)$. Graphically, RSM can be expressed in either three-dimensional space or contour plots to visualize the shape, according to Eq. 3. Correspondingly, RSM was followed as quadratic and polynomial equation, which was developed for prediction of experimental actual values, taken as the function of independent variables and their interactions (Goel et al. 2006; Zulkali et al. 2006). The second-order polynomial regression model follows equation (Eq. 4), which can be described as

$Y=\beta_{0}+\sum \beta_{i} X_{i}+\sum \beta_{i i} X_{i}^{2}+\sum \beta_{i j} X_{i} X_{j}+\varepsilon$

In terms of $\beta_{0}, \beta_{i}, \beta_{i j}$ are the regression coefficient and interaction variable factors, while $Y$ is the response vector for the percentage of adsorption (glyphosate uptake). The 
parameters (e.g., dose, concentration, $\mathrm{pH}$ ) are independent variables $X_{i}, X_{j}$, and $\varepsilon$ is the error term (Chattoraj et al. 2013). Model fitness is determined using $R^{2}$. The known $\beta$ is obtained by the least-squares technique, which minimizes the sum of the squares of the residuals. The estimated parameters are as follows:

$$
\begin{aligned}
Y= & \beta_{0}+\beta_{1} X_{1}+\beta_{2} X_{2}+\beta_{3} X_{3}+\beta_{4} X_{4}+\beta_{5} X_{5} \\
& +\beta_{11} X_{1}^{2}+\beta_{22} X_{2}^{2}+\beta_{33} X_{3}^{2}+\beta_{44} X_{4}^{2}+\beta_{55} X_{5}^{2} \\
& +\beta_{12} X_{1} X_{2}+\beta_{13} X_{1} X_{3}+\beta_{14} X_{1} X_{4}+\beta_{15} X_{1} X_{5} \\
& +\beta_{23} X_{2} X_{3}+\beta_{24} X_{2} X_{4}+\beta_{25} X_{2} X_{5}+\beta_{34} X_{3} X_{4} \\
& +\beta_{35} X_{3} X_{5}+\beta_{45} X_{4} X_{5}
\end{aligned}
$$

The coefficient of the model for the output response was estimated using Eq. 9, where multiple regression analysis included the model fitting quality, which was determined as the model coefficient. This approach is based on probable glyphosate removal as the response $(Y)$, and the individual parameters are the varying optimized function $\left(d_{i}\right)$ coded range into $\left(0 \leq d_{i} \leq 1\right)$ (Harrington 1965; Derringer and Suich 1980). Then the variable adequacy is selected to obtain the optimal desirability by the following equation:

$D=\left(d_{1} \times d_{2} \times d_{3} \times \cdots d_{n}\right)^{\frac{1}{n}}$

where $n$ is the number of responses measured and assigned ranges in the maximum, minimum, and targets.

\section{Modeling evaluation}

Statistical analysis was conducted to determine experimental error and statistical significance. In the present work, the acceptability of the model was determined by using analysis of variance (ANOVA). Model adequacy test needful for analysis of experimental data, and the model has been justified by $F$ value and $p$ values. All engaged parameters dependencies has been determined as 3D graphical plots with response variables, perturbation for parameter adequacy, predictive on experimental with model (actual vs. predicted) and ramp test for desirable function (Wachter and Cordery 1999).

\section{Desorption experiment}

The exhausted adsorbent was regenerated with 0.1 (M) $\mathrm{HCl}$, $\mathrm{HNO}_{3}, \mathrm{H}_{2} \mathrm{SO}_{4}, \mathrm{CH}_{3} \mathrm{COOH}$, and $\mathrm{NaOH}$ for glyphosate recovery. For the desorption study, glyphosate-loaded EBAC was dried, placed in the above-mentioned solutions, and stirred for 2 (h) at $320 \mathrm{rpm}$. Desorption efficiency was calculated according to Eq. (7):

Desorption efficiency $(\%)=\frac{\text { Desorption amount }}{\text { Adsorption amount }} \times 100$

\section{Results and discussion}

\section{Characterization of adsorbent}

The adsorbent characterization was performed by various analytical techniques including BET surface area, FTIR, and physicochemical analysis (moisture content, bulk density, particle density, porosity), and the results are summarized in Table 1. The FTIR spectral signature of EBAC, both before and after loading of glyphosate, is depicted in Fig. 1. It is clearly revealed that the peaks at $626.91,1027.78,1178.10,1292.40,1729.11,2374.14$, $2932.27,3390.70$, and $3663.01 \mathrm{~cm}^{-1}$ correspond to the functional groups (Herath et al. 2015). The broad and intense band at $3390 \mathrm{~cm}^{-1}$ indicates the presence of $-\mathrm{OH}$ stretching (Xu et al. 2011). Similarly, the sharp peak at $2932.27 \mathrm{~cm}^{-1}$ is attributed to $\mathrm{C}-\mathrm{H}$ asymmetric stretching. The peak at $1729.11 \mathrm{~cm}^{-1}$ is attributed to the presence of a C-O-P linkage, while peaks at $1178.10 \mathrm{~cm}^{-1}$, $1027.78 \mathrm{~cm}^{-1}$, and $1292.40 \mathrm{~cm}^{-1}$ are attributed to organophosphorus ( $\mathrm{P}=\mathrm{O}$ stretching), $\mathrm{C}-\mathrm{O}$ stretching, and $\mathrm{C}-\mathrm{NH}_{2}$ stretching vibrations before and after glyphosate loading of EBAC (Coates 2000; Smidt et al. 2011). The vibration peaks at $626.91 \mathrm{~cm}^{-1}$ clearly indicate the aromatic - CH stretching (Foo and Hameed 2011). The glyphosate loaded adsorbent showed the $\mathrm{C}-\mathrm{H}$ stretching is asymmetric in form.

Table 1 Physicochemical characterization of EBAC

\begin{tabular}{lc}
\hline Characteristics & \multicolumn{1}{l}{ Values } \\
\hline BET surface area $\left(\mathrm{m}^{2} \mathrm{~g}^{-1}\right)$ & $0.54 \pm 0.01$ \\
$\mathrm{pH}$ & $6.8 \pm 0.31$ \\
$\mathrm{pH}_{\text {zpc }}$ & $8.38 \pm 1.11$ \\
Bulk density $\left(\mathrm{g} \mathrm{cm}^{-3}\right)$ & $0.232 \pm 0.023$ \\
Porosity (\%) & $11.22 \pm 2.55$ \\
Moisture content (\%) & $11.12 \pm 0.48$ \\
Ash content $(\%)$ & $20.23 \pm 0.23$ \\
Volatile matter $(\%)$ & $61.93 \pm 2.11$ \\
Fixed carbon $(\%)$ & $14.74 \pm 0.52$ \\
Carbon $(\%)$ & $45.32 \pm 1.32$ \\
Nitrogen $(\%)$ & $0.42 \pm 0.01$ \\
Specific gravity $_{\text {Conductivity }\left(\mathrm{S} \mathrm{cm}^{-1}\right)}$ & $0.187 \pm 0.002$ \\
$\mathrm{Na}^{+}\left(\mathrm{mg} \mathrm{L}^{-1}\right)$ & $1.12 \pm 0.02$ \\
$\mathrm{~K}^{+}(\mathrm{mg} \mathrm{L}$ & \\
\hline
\end{tabular}

Mean of three replicates \pm SE 
Fig. 1 FTIR study before (black line) and after (red line) adsorption of glyphosate on adsorbent

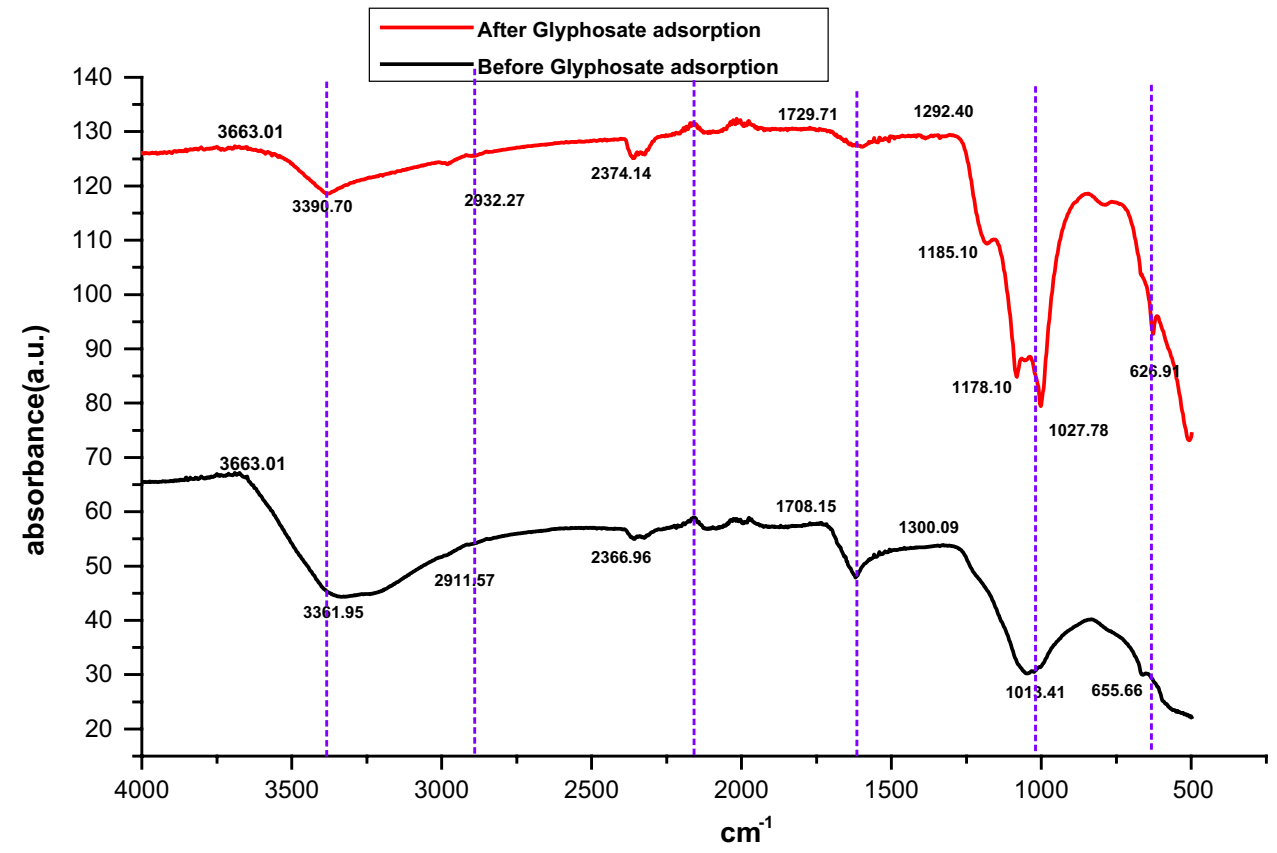

\section{Batch adsorption study}

\section{Influence of initial glyphosate concentration}

The entire batch study was performed with glyphosate solution, with concentrations ranging from 5 to $30 \mathrm{mg} \mathrm{L}^{-1}$, and constant variables of $\mathrm{pH}$ (7.0) and contact time (30 min). The performance at various concentrations, showing the response between uptake capacity and uptake percentage, is presented in Figure $\mathrm{S} 1$. The glyphosate adsorption capacity of EBAC varied from 1.5 to $12 \mathrm{mg} \mathrm{g}^{-1}$, with the results clearly showing that adsorption capacity increased with increasing concentration (Fig. S1). The uptake capacity increased gradually until reaching a saturation point, and then decreased. Fixed amount dose has saturated, due to possible site can be exceed; glyphosate molecules has prevent driven force for interacting of EBAC adsorbents. This may be attributed to the gradual increase in mass concentration, which may have had sufficient driving force to overcome the mass transfer resistance (Wanyonyi et al. 2014).

\section{Influence of $\mathrm{pH}$}

$\mathrm{pH}$ is a fundamental component that strongly influences the absorption of pollutants on the adsorbent surface. At low $\mathrm{pH}$, the EBAC surface becomes positively charged, due to adherance of $\mathrm{H}^{+}$ions on the surface. However, at higher $\mathrm{pH}$, the surface is negatively charged due to $\mathrm{OH}^{-}$ions. The results of the present study demonstrate that glyphosate adsorption is favorable at $\mathrm{pH}$ 14.0, with $93.34 \%$ adsorption (Fig. S2). When $\mathrm{pH}_{\mathrm{zpc}}>\mathrm{pH}$, system is below $\mathrm{pH}_{\mathrm{zpc}}$, give more protons than hydroxide groups, surface is positive ions donate, affinity negative ions; similarly $\mathrm{pH}_{\mathrm{zpc}}<\mathrm{pH}$, the higher $\mathrm{pH}_{\mathrm{zpc}}$ formed to negative surface donate more hydroxide groups, attracting positive ions (Mondal et al. 2019a). Moreover, this $\mathrm{pH}$ is above the $\mathrm{pH}_{\mathrm{zpc}}$ of EBAC, therefore clearly support the adsorption of glyphosate. The present finding is in agreement with our earlier study (Sen et al. 2017). A tentative electrostatic interaction mechanism is presented as follows (Bhaumik and Mondal 2016):

$$
\begin{aligned}
& \equiv \text { EBAC }+\mathrm{OH}^{-}+\mathrm{H}-\mathrm{N}=\text { glyphosate }-\mathrm{P}_{\|}-\rightarrow \\
& \equiv \text { EBAC }-\mathrm{OH}^{-} \ldots \mathrm{O}=\mathrm{P}-\text { glyphosate }=\mathrm{N}-\mathrm{H}
\end{aligned}
$$

Similar interaction between pollutants and adsorbent surface was reported in an earlier study (Nam et al. 2014).

\section{Influence of adsorbent dose}

The effect of EBAC dose on glyphosate adsorption is shown in Figure S3, with the respective constant parameters of contact time of $30 \mathrm{~min}, \mathrm{pH} 7$, concentration of $30 \mathrm{mg} \mathrm{L}^{-1}$, and temperature $303 \mathrm{~K}$, and the variable of EBAC dose (5-200 $\mathrm{mg}$ ) in respective $50 \mathrm{~mL}$ glyphosate solution. The glyphosate increased from 71.64 to $77.44 \%$ when the EBAC dose was increased from 5 to $100 \mathrm{mg}$, then reached a saturation point, and a further increase in dose above $100 \mathrm{mg}$ produced no significant change in adsorption. This is perhaps due to the enhanced availability of active sites, which support glyphosate binding. The results also revealed that beyond an adsorbent dose of $150 \mathrm{mg} / 50 \mathrm{~mL}$, no further 
increase in adsorption occurs. This can be explained by the fact that at the higher dose, some of the active sites overlapped, thus reducing the adsorption performance (Malik et al. 2007; Chattoraj et al. 2016).

\section{Influence of contact time}

Contact time is the most important factor in the adsorption process, where adsorption rate can interact with glyphosate molecules and EBAC. The effect of contact time on glyphosate adsorption is presented in Figure S4. The results reveal that maximum adsorption of $89 \%$ was recorded at $120 \mathrm{~min}$. After $120 \mathrm{~min}$, the adsorption rate did not change significantly. This phenomenon can occur, where binding sites does not fill in primarily; then increased collision rate between adsorbate and adsorbent, where concentration of glyphosate molecules has present in large amount of availability sites. Rate has become slow, because of that fill up the activated site of EBAC then released the adopting glyphosate molecules, due to repulsing between adsorbate and adsorbent (Chowdhury et al. 2011). As longer time make a collision phenomenon increases between particle of adsorbate and adsorbents; for this reason, no significant phenomena occurred after $120 \mathrm{~min}$.

\section{Influence of temperature}

Temperature is an important operating parameter that directly influences the adsorption reaction (Mondal and Roy 2018). In this study, temperature values of 300-373 K were used, and the corresponding removal percentages are depicted in Figure S5. The results clearly show that glyphosate adsorption gradually increased with increasing temperature, with maximum adsorption of $97.84 \%$ recorded at $373 \mathrm{~K}$. As the adsorption rate tends to increase at higher temperature, the binding force may deteriorate at lower temperature; therefore, the adsorbate-adsorbent interaction is endothermic in nature. Similar results have been observed for adsorption of organic pollutants (Ghosh et al. 2016). At higher temperature, the pollutants depart from the surface of the adsorbents due to the weakened force of interaction (Li et al. 2013).

\section{Equilibrium isotherms}

Isotherm models have played a major role in describing the adsorption mechanism. These include the Langmuir, Freundlich, Temkin, and D-R models, as summarized in Table 2. The Langmuir isotherm capacity of glyphosate adsorption is $66.76 \mathrm{mg} \mathrm{g}^{-1}$, with a monolayer affinity $\left(K_{\mathrm{L}}\right)$ value of 0.178 . The separation factor $\left(R_{\mathrm{L}}\right)$ was calculated, where adsorption with positive $\left(0<R_{\mathrm{L}}<1\right)$ subordinating points varied from 0.56 to 0.15 (Fig. S6). The experimental results indicated that the Freundlich isotherm showed the best fit $\left(R^{2}=0.988\right)$ of the adsorption model. The Freundlich affinity $\left(K_{\mathrm{F}}\right)$ and exponent $(n)$ values are $K_{\mathrm{F}}$ for $9.64 \mathrm{mg} \mathrm{g}^{-1}\left(\mathrm{~L} \mathrm{mg}^{-1}\right)^{1 / n}$ and $n$ for 9.259 , respectively. However, the value of $n$ is classified from 1 to 10 ( $n$ value is highly exposed to EBAC for glyphosate molecules); consequently, the results may suggest that the absorption is appropriate with physisorption nature (Chowdhury et al. 2011). The Temkin constant $\left(b_{\mathrm{T}}\right)$ confirms that the energy required for glyphosate binding with EBAC molecules is $21.375 \mathrm{~kJ} \mathrm{~mol}^{-1}$. In addition, the D-R isotherm was estimated for the $\mathrm{E}$ value $\left(4.082 \mathrm{~kJ} \mathrm{~mol}^{-1}\right)$, and indicated a physisorption process (Dada et al. 2012).

\section{Adsorption kinetics}

Kinetic models are used to describe the adsorption mechanism, which is associated with the adsorption rate by pseudo-first-order (Lagergren 1898) and pseudosecond-order kinetics (Ho and McKay 1999), are shown in Table 3. The linear equation is given in Table 3 and calculated by Chattoraj et al. (2016). All kinetic data are presented in Table 3. The results reveal that the pseudo-first-order model was fitted in linear terms, but

Table 2 Isotherm data for adsorption of glyphosate by EBAC

\begin{tabular}{|c|c|c|c|c|c|}
\hline Adsorption isotherm & Equations & Eq. nos. & Parameters (unit) & Values & $R^{2}$ \\
\hline Langmuir & $\frac{1}{q_{\mathrm{e}}}=\frac{1}{q_{\max } K_{\mathrm{L}} C_{\mathrm{e}}}+\frac{1}{q_{\max }}$ & (11) & $\begin{array}{l}q_{\max }\left(\mathrm{mg} \mathrm{g}^{-1}\right) \\
K_{\mathrm{L}}\left(\mathrm{L} \mathrm{mg}^{-1}\right)\end{array}$ & $\begin{array}{l}66.76 \\
0.178\end{array}$ & 0.9589 \\
\hline Freundlich & $\log q_{\mathrm{e}}=\log k_{\mathrm{F}}+\frac{1}{n} \log C_{\mathrm{e}}$ & (12) & $\underset{n}{K_{\mathrm{F}}\left(\mathrm{mg} \mathrm{g}^{-1}\right)\left(\mathrm{L} \mathrm{mg}^{-1}\right)^{1 / n}}$ & $\begin{array}{l}9.64 \\
9.259\end{array}$ & 0.988 \\
\hline Temkin & $q_{\mathrm{e}}=\frac{R T}{b_{\mathrm{T}}}\left(\ln A_{\mathrm{T}}+\ln C_{\mathrm{e}}\right)$ & (13) & $\begin{array}{l}A_{\mathrm{T}}\left(\mathrm{L} \mathrm{mg}^{-1}\right) \\
b_{\mathrm{T}}\left(\mathrm{kJ} \mathrm{mol}^{-1}\right)\end{array}$ & $\begin{array}{l}0.97 \\
21.375\end{array}$ & 0.9708 \\
\hline $\mathrm{D}-\mathrm{R}$ & $\ln q_{\mathrm{e}}=\ln q_{\mathrm{max}}-\frac{1}{2 E^{2}} \times\left[R T \ln \left(1+\frac{1}{C_{\mathrm{e}}}\right)^{2}\right]$ & (14) & $\begin{array}{l}q_{\max }\left(\mu \mathrm{gg}^{-1}\right) \\
E\left(\mathrm{~kJ} \mathrm{~mol}^{-1}\right)\end{array}$ & $\begin{array}{l}8.46 \\
64.082\end{array}$ & 0.9729 \\
\hline
\end{tabular}

Here, $q_{\max }$ is the maximum adsorption capacity; $K_{\mathrm{L}}, K_{\mathrm{F}}, A_{\mathrm{T}}$, and $b_{\mathrm{T}}$ are different adsorption constants; $n$ is the heterogeneity factor; $E$ is the mean free energy of adsorption per mole of adsorbate; $T$ is the temperature $(\mathrm{K})$; and $R$ is the ideal gas constant $\left(8.3145 \mathrm{~J} \mathrm{~mol}{ }^{-1} \mathrm{~K}\right)$ 
Table 3 Summary of adsorption parameters for various kinetic models

\begin{tabular}{|c|c|c|c|c|c|}
\hline Kinetic model & Equations & Eq. nos. & Parameters (unit) & Values & $R^{2}$ \\
\hline Pseudo-first-order & $\ln \left(q_{\mathrm{e}}-q_{t}\right)=\ln q_{\mathrm{e}}-K_{1} t$ & $(15)$ & $\begin{array}{l}q_{\mathrm{e}}\left(\mu \mathrm{g} \mathrm{g}^{-1}\right) \\
K_{1}\left(\min ^{-1}\right)\end{array}$ & $\begin{array}{l}3.650 \\
0.1359\end{array}$ & 0.977 \\
\hline Pseudo-second-order & $\frac{t}{q_{t}}=\frac{1}{K_{2} q_{\mathrm{e}}^{2}}+\frac{t}{q_{\mathrm{e}}}$ & $(16)$ & 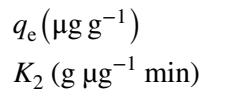 & $\begin{array}{l}3.077 \\
1.447\end{array}$ & 1.0 \\
\hline Boyd kinetics model & $B_{t}=-0.4977-\ln (1-F)$ & $(17)$ & - & - & 0.7617 \\
\hline Intra-particle diffusion & $q_{t}=k_{d} t^{\frac{1}{2}}+I$ & $(18)$ & $\begin{array}{l}k_{d}\left(\mathrm{mg} \mathrm{g}^{-1} \min ^{-1 / 2}\right) \\
I\left(\mathrm{mg} \mathrm{g}^{-1}\right)\end{array}$ & $\begin{array}{l}4.036 \\
0.808\end{array}$ & 0.6108 \\
\hline
\end{tabular}

$q_{t}$ is the adsorption capacity at time $t ; K_{1}$ and $K_{2}$ are the first-order and second-order rate constants, respectively, and $B_{t}$ against time (min) $F$ represents the fraction of solute adsorbed at any time $t(\mathrm{~min})$, as calculated from $F=q_{t} / q_{\mathrm{e}}$ the pseudo-second-order kinetic model $\left(R^{2}=1.0\right)$ showed an excellent fit compared with the other models. The adsorption rate constant and adsorption capacity are $30.77\left(\mathrm{mg} \mathrm{g}^{-1}\right)$ and $1.447\left(\mathrm{~min}^{-1}\right)$, respectively. Possible phenomena of this process, chemical sorption has played major role, sharing or exchange of electrons between glyphosate and EBAC (Hameed et al. 2009). The pore diffusion mechanism is determined from Eq. 18, which shows that pore diffusion played a significant role in adsorption. The results suggest that adsorption involved a slow, controlled stepwise process, and therefore subjected to Boyd kinetic analysis. Some particles participated in the diffusion mechanism of glyphosate ions, which traveled through the pore phases of EBAC in a limited amount $\left(R^{2}=0.7617\right)$ such that the adsorption phenomena mostly involved interacted with the exterior surface of the adsorbent (Tan and Hameed 2010).

\section{Activation energy and thermodynamic parameters}

The activation energy was calculated from the Arrhenius equation (Table 4), which was plotted between $\ln K$ and $1 / T$. Activation energy was obtained from the slope of the linear plot, with a value of $101.23 \mathrm{~kJ} \mathrm{~mol}^{-1}$. The energy of this adsorption therefore suggests that the adsorption process is controlled by the magnitude of the chemical interaction between adsorbent and adsorbate (Chen et al. 2016). The thermodynamic parameters are determined from the adsorption equilibrium constant $K_{\mathrm{c}}$, where $K_{\mathrm{c}}$ is the ratio of the adsorption capacity $\left(\mathrm{mg} \mathrm{g}^{-1}\right)$ and the concentration at the equilibrium state. The thermodynamic parameters $\left(\Delta G^{\circ}\right.$, $\Delta H^{\circ}$, and $\Delta S^{\circ}$ ) for the adsorption of glyphosate on EBAC were calculated as follows:

$\Delta G^{\circ}=-R T \ln K_{\mathrm{c}}$

where $R$ is the ideal gas constant, $T$ is the temperature (K), and $K_{\mathrm{c}}$ is the distribution coefficient calculated from the
Table 4 Thermodynamic parameters of glyphosate adsorption by EBAC

\begin{tabular}{llll}
\hline Thermodynamic parameters & Equations & Eq. nos. & Values $\left(\mathrm{J} \mathrm{mol}^{-1}\right)$ \\
\hline Standard free energy & $\Delta G^{\circ}=-R T \ln K_{\mathrm{c}}$ & $(19)$ & -1166.49 \\
$303 \mathrm{~K}$ & & & -1200.43 \\
$313 \mathrm{~K}$ & & -1312.42 \\
$323 \mathrm{~K}$ & & -1398.92 \\
$333 \mathrm{~K}$ & & -1482.89 \\
$343 \mathrm{~K}$ & & -1495.33 \\
$353 \mathrm{~K}$ & & -1799.71 \\
$363 \mathrm{~K}$ & & -3097.94 \\
$373 \mathrm{~K}$ & $\ln K_{\mathrm{c}}=\frac{\Delta S^{\circ}}{R}-\frac{\Delta H^{\circ}}{R T}$ & $(20)$ & -20.416 \\
Standard enthalpy change & & & -5281.3 \\
Standard entropy change & $\ln K=\frac{-E a}{R T}+\ln A$ & $(21)$ & $106,420.50$ \\
Activation energy by Arrhenius & & \\
equation & & & \\
\hline
\end{tabular}

$K_{\mathrm{C}}$ is the equilibrium constant, and $T$ and $R$ are the Kelvin temperature and molar gas constant, respectively. The pre-exponential factor, $A$ (which is the largest rate constant that the reaction can possibly have) can be evaluated from any measure of the absolute rate constant of the reaction 
experiment and Van 't Hoff plots of 1/T versus $\ln K_{\mathrm{c}}$ (Fig. S7). The values of $\Delta H^{\circ}$ and $\Delta \mathrm{S}^{\circ}$ were calculated from the slope and intercept of the Van 't Hoff plots, as listed in Table 4. The negative values of free energy $\Delta G^{\circ}$ indicate that the adsorption process is spontaneous in nature and more energy-efficient. The negative values of $\Delta H^{\circ}$ suggest the exothermic nature of the adsorption process. The negative value of $\Delta S^{\circ}$ confirms increasing randomness with increased temperature, perhaps due to the solid-solution interaction triggered between glyphosate and EBAC. The thermodynamic values of the adsorption parameters were reported in a previous study and are in good agreement with those in the literature (Sen et al. 2017; Chen et al. 2016). The negative value of $\Delta S^{\circ}\left(-220 \mathrm{~J} \mathrm{~mol}^{-1}\right)$ suggests that the process is enthalpy-driven.

\section{Model fitting and statistical analysis}

Box-Behnken design was applied for response surface analysis with operating variables. This statistical model was validated with corresponding correlation coefficient $\left(R^{2}\right)$. The selected model was aliased with quadratic type, adjusted $R$-squared and predicted $R$-squared values. An empirical relationship expressed by a second-order polynomial from Eq. 9, as followings:

$$
\begin{aligned}
\text { Removal }(\%)= & 83.26-0.79 A+1.53 B+11.54 C \\
& +1.70 D+12.41 E-0.11 A B-0.13 A C \\
& +0.26 A D+0.87 A E+0.25 B C-0.27 B D \\
& +0.28 B E-0.067 C D-0.55 C E+0.083 D E \\
& +11.25 A 2-4.17 B^{2}-10.93 C^{2}+2.13 D^{2} \\
& -27.16 E^{2}
\end{aligned}
$$

where $A, B, C, D$, and $E$ are the dose, contact time, $\mathrm{pH}$, temperature, and glyphosate concentration, respectively. Apart of model ensures that model are well fitted of experimental results through the analysis of variance (ANOVA), is shown in Table 5. The Fisher value ( $F$ value) is very high (63.48) and the $p$ value is less than 0.0001 . The ratio of the $p$ and $F$
Table 5 Analysis of variance for the response of the adsorption

\begin{tabular}{|c|c|c|c|c|c|}
\hline Source & Sum of squares & $d f$ & Mean square & $F$ value & $p$ value $(\operatorname{Prob}>F)$ \\
\hline Model & 210.09 & 20 & 10.5 & 63.48 & $<0.0001$ \\
\hline A-dose & 1.022 & 1 & 1.022 & 6.176 & 0.0347 \\
\hline B-contact time & 2.14 & 1 & 2.14 & 12.93 & 0.0058 \\
\hline $\mathrm{C}-\mathrm{pH}$ & 18.664 & 1 & 18.66 & 112.78 & $<0.0001$ \\
\hline D-temperature & 2.298 & 1 & 2.298 & 13.88 & 0.0047 \\
\hline E-concentration & 21 & 1 & 21 & 126.91 & $<0.0001$ \\
\hline $\mathrm{AB}$ & 0.021 & 1 & 0.022 & 0.128 & 0.7282 \\
\hline $\mathrm{AC}$ & 0.012 & 1 & 0.013 & 0.076 & 0.7881 \\
\hline $\mathrm{AD}$ & 0.107 & 1 & 0.11 & 0.647 & 0.4419 \\
\hline $\mathrm{AE}$ & 0.131 & 1 & 0.131 & 0.794 & 0.3959 \\
\hline $\mathrm{BC}$ & 0.012 & 1 & 0.012 & 0.074 & 0.7915 \\
\hline $\mathrm{BD}$ & 0.053 & 1 & 0.053 & 0.322 & 0.5839 \\
\hline $\mathrm{BE}$ & 0.005 & 1 & 0.005 & 0.033 & 0.8602 \\
\hline $\mathrm{CD}$ & 0.001 & 1 & 0.001 & 0.006 & 0.9391 \\
\hline $\mathrm{CE}$ & 0.008 & 1 & 0.008 & 0.052 & 0.824 \\
\hline $\mathrm{DE}$ & 0.001 & 1 & 0.001 & 0.004 & 0.9491 \\
\hline $\mathrm{A}^{\wedge} 2$ & 106.648 & 1 & 106.65 & 644.46 & $<0.0001$ \\
\hline $\mathrm{B}^{\wedge} 2$ & 10.851 & 1 & 10.85 & 65.57 & $<0.0001$ \\
\hline $\mathrm{C}^{\wedge} 2$ & 9.784 & 1 & 9.78 & 59.12 & $<0.0001$ \\
\hline $\mathrm{D}^{\wedge} 2$ & 4.432 & 1 & 4.43 & 26.78 & 0.0006 \\
\hline$E^{\wedge} 2$ & 19.143 & 1 & 19.14 & 115.67 & $<0.0001$ \\
\hline Residual & 1.489 & 9 & 0.165 & & \\
\hline Cor total & 211.59 & 29 & 7.296 & & \\
\hline Pure error & 1.478 & 8 & 0.184 & & \\
\hline Lack of fit & 0.011 & 1 & 0.011 & 0.059 & 0.810 \\
\hline SD & 0.41 & & & $R$-squared & 0.993 \\
\hline Mean & 90.89 & & & Adj $R$-squared & 0.9773 \\
\hline $\mathrm{CV}(\%)$ & 0.45 & & & Pred $R$-squared & 0.753 \\
\hline Press & 52.26 & & & Adeq precision & 30.1 \\
\hline
\end{tabular}
capacity for glyphosate 
values is less than 0.05 . Therefore, the $F$ value is nonsignificant and the $p$ value is significant, there model is significant with high coefficient value $\left(R^{2}=0.993\right)$. The lack of fit value is 1.91 (more than $0.01 / 0.05$ ), which is nonsignificant, meaning that the quadratic model is acceptable for this study. The significance of the regression coefficient values of the parameter are determined by the Student $t$ test. In addition, a perturbation plot is derived for model implementation, and a comparison of all responsible factors in design space is shown in this perturbation plot (Fig. S8). All factors (dose, contact time, $\mathrm{pH}$, concentration, temperature) have a significant effect on glyphosate adsorption, because all nonlinear bias uniformly merges at a zero coded deviation, helping to identify the sensitivity of the design parameters (Inama et al. 2017). A 3D plot of the interaction of different variables with removal response is shown in Fig. S9(A-J). The graphical plot is able to identify the maximum response, and the functions of the dependent variables (e.g., pH, EBAC dose, temperature, glyphosate concentration, contact time). A similar observation was seen with pesticide adsorption optimization (Chattoraj et al. (2016).

\section{Optimization using the desirability function}

Optimization of the input parameters including initial concentration, $\mathrm{pH}$, dose, and temperature was carried out in terms of maximum, minimum, and targets. The desirability function was calculated from the ramp test (Fig. S10). The actual and predicted glyphosate removal efficiency is plotted in Fig. S9 (L), and the normal distribution for parametric assumptions of residuals is plotted in Fig. S9 (K). The desirability function was similarly applied to output response for pesticide adsorption (Sen et al. 2017; Chattoraj et al. 2016). This model indicated maximum removal efficiency at the minimum dose, showing suitable results with a calculated desirability of 1 (Mourabet et al. 2015; Chattoraj et al. 2018). In numerical terms, maximum glyphosate adsorption of $98 \%$ was achieved at a dose of $199.92 \mathrm{mg}$, contact time of 78.42 min, $\mathrm{pH} 10.18$, and temperature of $30.23{ }^{\circ} \mathrm{C}$.

\section{Desorption studies}

The potential for reuse/recycling of the adsorbent materials was examined using various agents including $\mathrm{HCl}, \mathrm{HNO}_{3}$, $\mathrm{H}_{2} \mathrm{SO}_{4}, \mathrm{CH}_{3} \mathrm{COOH}$, and $\mathrm{NaOH}$ in $0.1(\mathrm{M})$ solution. A comparison plot is shown in Fig. S11. The results show approximately $76.33 \%$ recovery of glyphosate from $\mathrm{EBAC}$ by $\mathrm{HCl}$, indicating better recovery in an acid medium. Therefore, $\mathrm{HCl}$ can be used for deprotonation of glyphosate ions in an aqueous medium, which breaks down the cationic bonds of the EBAC adsorbent (Tan and Hameed 2010), with maximum desorption as well as greater efficiency.

\section{Possible mechanisms for glyphosate adsorption}

The present study of isotherms and kinetics model implicated either physisorption or chemisorption. The van der Waals force occurs mainly by the dipole interaction, where electrons are donated and accepted through $\mathrm{H}$-bond interactions (Herath et al. 2016). The surface area suggests that the EBAC is a good porous surface (BET surface $0.54 \pm 0.01$ $\mathrm{m}^{2} \mathrm{~g}^{-1}$ ), enabling the physical interaction of adsorbate and adsorbent through a diffusion mechanism. Therefore, pseudo-second-order kinetic diffusion, the primary mechanism involved in physisorption, interacts by polarized bonds through heterogeneous interference. On the other hand, a value of $\mathrm{pH}<\mathrm{pH}_{\mathrm{zpc}}$ indicates that more protons are donated than hydroxyl ions. Therefore, the adsorbent surface is positively charged (attracting glyphosate anions), the ion distribution of glyphosate of protonated amino group, bound with carbon atoms, forming strong $\pi-\pi$ electron interactions, it is positively indicated at FTIR peak on $1027.17 \mathrm{~cm}^{-1}$ stretching (Kirby 2010). The chemisorption mechanism was obtained, and clearly indicated that higher temperature increased the adsorption process (showing a thermodynamic function as exothermic in nature). This is probably due to interactions through electrostatic, electrophilic, and $\pi-\pi$ electron donor-acceptor of the negative phosphonate group of glyphosate ions with aromatic phenolic group at $626.91 \mathrm{~cm}^{-1}$ and $1027.78 \mathrm{~cm}^{-1}$ (Foo and Hameed 2011). A part of the glyphosate molecule of the amino group was ionized in alkali medium, and the results show increased adsorption with increasing $\mathrm{pH}$. In addition, the results of kinetic and thermodynamic modeling suggest that both physisorption and chemisorption processes may be involved in adsorption onto EBAC (graphical mechanism in Fig. S12).

\section{Comparison of current study with previously published reports}

Previous studies in the literature have investigated glyphosate adsorption of various adsorbent doses. A comparison of the results is presented in Table 6, which shows high adsorbent capacity for resin D301 (Chen et al. 2016), Zr-MOF (Yang et al. 2018), biochar-supported nano-zerovalent iron (Jiang et al. 2018), $\mathrm{MnFe}_{2} \mathrm{O}_{4}$-graphene hybrid composite (Yamaguchi et al. 2016), forest soil (Sen et al. 2017), rice husk char (Herath et al. 2016), woody biochar (Mayakaduwa et al. 2016), palm oil frond-activated carbon (Salman and Abid 2013), alum sludge in liquid form (LAS) (Hu et al. 2011), and dewatered alum sludge (DAS) (Hu et al. 2011). The adsorption capacity for glyphosate, in descending order, is as follows: resin D301 $>\mathrm{Zr}-\mathrm{MOF}>\mathrm{MnFe}_{2} \mathrm{O}_{4}$-graphene

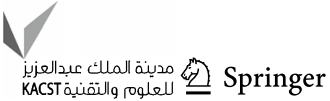


Table 6 Comparison of glyphosate adsorption capacity of various adsorbents

\begin{tabular}{lll}
\hline Adsorbent & $\begin{array}{l}\text { Adsorption capacity } \\
\left(\mathrm{mg} \mathrm{g}^{-1}\right)\end{array}$ & References \\
\hline Eucalyptus bark-activated char (EBAC) & 66.76 & Current study \\
Biochar-supported nano-zerovalent iron & 45.8 & Jiang et al. (2018) \\
Zr-MOF & 256.54 & Yang et al. (2018) \\
Forest soil & 161.29 & Sen et al. (2017) \\
Woody biochar & 44 & Mayakaduwa et al. (2016) \\
MnFe $_{2} \mathrm{O}_{4}-$ graphene hybrid composite & 204.2 & Yamaguchi et al. (2016) \\
Rice husk char & 123.03 & Herath et al. (2015) \\
Resin D301 & 833.33 & Chen et al. (2016) \\
Alum sludge (liquid form [LAS]) & 113.6 & Hu et al. (2011) \\
Dewatered alum sludge (DAS) & 85.9 & Hu et al. (2011) \\
\hline
\end{tabular}

hybrid composite $>$ forest soil $>$ rice husk char $>$ LAS $>$ palm oil fronds $>$ activated carbon $>$ DAS $>$ EBAC $>$ biochar-supported nano-zerovalent iron $>$ woody biochar. A recent study proposed the use of a dendrimer adsorbent (Guo et al. 2019) for the rapid removal of glyphosate from water samples, which reached adsorption equilibrium at $5 \mathrm{~min}$, but used adsorbent management was very difficult. Therefore, resin D301 exhibited maximum glyphosate adsorption potential previously, but moderate performance in the current study. Resin D301 has been shown to be very cost-efficient, which agrees with the current observation. On the other hand, the maximum removal efficiency for glyphosate absorption was found with EBAC, in comparison with moderate capacity for other adsorbents. However, the current study shows that EBAC demonstrates higher removal efficiency than other absorbents.

\section{Conclusions}

In the present study, EBAC synthesis was successfully applied for glyphosate removal from aqueous solution. The results revealed that acid-activated char has porous surface and thus greater capacity for removing glyphosate. Characterization was carried out by FTIR study and comparing the results before and after glyphosate loading of EBAC. The mechanism of glyphosate adsorption was mainly dominated by various functional groups, namely amine, carboxylic, phosphate, phenolic, and aromatic ring. A higher temperature was found to increase the removal efficiency, revealing an endothermic nature. The adsorption kinetic rates were controlled by a pseudo-second-order model with a slightly porous diffusion mechanism. All isotherm models exhibited positive positioning held on both multilayer and monolayer. The mechanisms are described at physisorption and chemisorption on a heterogeneous surface, maximum capacity $66.76 \mathrm{mg} \mathrm{g}^{-1}$, with $97.84 \%$ uptake efficiency. The removal efficiency according to independent findings through the
Box-Behnken design model shows optimal conditions as follows: $\mathrm{pH} 10.18$, dose $199.92 \mathrm{mg}$. $50 \mathrm{~mL}^{-1}$, concentration $20.28 \mathrm{mg} \mathrm{L}^{-1}$, contact time $78.42 \mathrm{~min}$, and temperature $303.23 \mathrm{~K}$. Therefore, this research shows the capacity for glyphosate remediation from agricultural wastewater. Finally, the results suggest that EBAC is a economically feasible biosorbent for glyphosate adsorption.

Acknowledgements The authors gratefully acknowledge the DST, Government of West Bengal, for financial support (WBDST Grant No. ST/P/SNT/15G-10/2015). The authors would also like to extend their sincere thanks to all faculty, including nonteaching staff, of the Department of Environmental Science, University of Burdwan, West Bengal, India, for their academic and moral support.

\section{Compliance with ethical standards}

Conflict of interest All the authors of this manuscript declare that they have no conflict of interest with regard to publication of this research article.

Open Access This article is distributed under the terms of the Creative Commons Attribution 4.0 International License (http://creativeco mmons.org/licenses/by/4.0/), which permits unrestricted use, distribution, and reproduction in any medium, provided you give appropriate credit to the original author(s) and the source, provide a link to the Creative Commons license, and indicate if changes were made.

\section{References}

Abbasi A, Sajid A, Haq N, Rahman S, Misbah Z, Sanober G, Ashraf A, Kazi AG (2014) Agricultural pollution: an emerging issue. Improv Crops Era Clim Changes 1:347-387

Akhtar M, Hasany SM, Bhanger MI, Iqbal S (2007) Low cost sorbents for the removal of methyl parathion pesticide from aqueous solution. Chemosphere 66:1829-1838

Al-Musawi TJ, Kamani H, Bazrafshan E, Panahi AH, Silva MF, Abi G (2019) Optimization the effects of physicochemical parameters on the degradation of cephalexin in Sono-Fenton reactor by using Box-Behnken response surface methodology. Catal Lett 149(5):1186-1196 
Bai SH, Ogbourne SM (2016) Glyphosate: environmental contamination, toxicity and potential risks to human health via food contamination. Environ Sci Pollut Res 23(19):18988-19001

Berg J, Brandt KK, Al-Soud WA, Holm PE, Hansen LH, Sorensen SJ, Nybroe O (2012) Selection for Cu-tolerant bacterial communities with altered composition, but unaltered richness, via long-term $\mathrm{Cu}$ exposure. Appl Environ Microbiol 78:7438-7446

Bhaskara BL, Nagaraja P (2006) Direct sensitive spectrophotometric determination of glyphosate by using ninhydrin as a chromogenic reagent in formulations and environmental water samples. Helv Chim Acta 89:2686-2693

Bhaumik R, Mondal NK (2016) Optimizing adsorption of fluoride from water by modified banana peel dust using response surface modelling approach. Appl Water Sci 6:115-135

Borggaard OK, Gimsing AL (2008) Fate of glyphosate in soil and the possibility of leaching to ground and surface waters: a review. Pest Manag Sci 64(4):441-456

Bourikas K, Vakros J, Kordulis C, Lycourghiotis A (2003) Potentiometric mass titrations: experimental and theoretical establishment of a new technique for determining the point of zero charge (PZC) of metal (hydr) oxides. J Phys Chem B 107:9441-9451

Chattoraj S, Sadhukhan B, Mondal NK (2013) Predictability by BoxBehnken model for carbaryl adsorption by soils of Indian origin. J Environ Sci Health B 48:626-636

Chattoraj S, Mondal NK, Sadhukhan B, Roy P, Roy TK (2016) Optimization of adsorption parameters for removal of carbaryl insecticide using neem bark dust by response surface methodology. Water Conserv Sci Eng 1:127-141

Chattoraj S, Mondal NK, Sen K (2018) Removal of carbaryl insecticide from aqueous solution using eggshell powder: a modeling study. Appl Water Sci 8:163

Chen F, Zhou C, Li G, Peng F (2016) Thermodynamics and kinetics of glyphosate adsorption on resin D301. Arab J Chem 9:S1665-S1669

Chowdhury S, Mishra R, Saha P, Kushwaha P (2011) Adsorption thermodynamics, kinetics and isosteric heat of adsorption of malachite green onto chemically modified rice husk. Desalination 265:159-168

Coates J (2000) Interpretation of infrared spectra, a practical approach. In: Meyers RA (ed) Encyclopedia of analytical chemistry. Willy, Chichester, pp 10815-10837

Cosgrove S, Jefferson B, Jarvis P (2019) Pesticide removal from drinking water sources by adsorption: a review. Environ Technol Rev $8(1): 1-24$

Cycon M, Wojcik M, Borymski S, Piotrowska-seget Z (2013) Shortterm effects of the herbicide napropamide on the activity and structure of the soil microbial community assessed by the multi approach analysis. Appl Soil Ecol 66:8-18

Dada AO, Olalekan AP, Olatunya AM, Dada O (2012) Langmuir, Freundlich, Temkin and Dubinin-Radushkevich isotherms studies of equilibrium sorption of $\mathrm{Zn}^{2+}$ unto phosphoric acid modified rice husk. J Appl Chem 3(1):38-45

Derringer G, Suich R (1980) Simultaneous optimization of several response variables. J Qual Technol 12:214-219

Djilani C, Zaghdoudi R, Djazi F, Bouchekima B, Lallam A, Modarressi A, Rogalski M (2015) Adsorption of dyes on activated carbon prepared from apricot stones and commercial activated carbon. J Taiwan Inst Chem Eng 53:112-121

Ermakova IT, Kiseleva NI, Shushkova T, Zharikov M, Zharikov GA, Leontievsky AA (2010) Bioremediation of glyphosate-contaminated soils. Appl Microbiol Biotechnol 88(2):585-594

Ferreira SLC, Bruns RE, da Silva EGP, dos Santos WNL, Quintella CM, David JM, Andrade JB, Breitkreitz MC, Jardim ICSF, Neto BB (2007) Statistical designs and response surface techniques for the optimization of chromatographic systems. J Chromatogr A $1158(1-2): 2-14$
Foo K, Hameed B (2011) Microwave assisted preparation of activated carbon from pomelo skin for the removal of anionic and cationic dyes. Chem Eng J 173:385-390

Ghosh SB, Mondal NK (2019) Application of Taguchi method for optimizing the process parameters for the removal of fluoride by Al-impregnated Eucalyptus bark ash. Environ Nano Monitor Manag 11:100206

Ghosh SB, Bhaumik R, Mondal NK (2016) Optimization study of adsorption parameters for removal of fluoride using aluminiumimpregnated potato plant ash by response surface methodology. Clean Technol Environ Policy 18:1069-1083

Global Industry Analyst Press Release 10 October 2011. Global glyphosate market to reach 1.35 million metric tons by 2017 , according to a new report by Global Industry Analysts, Inc

Goel J, Kadirvelu K, Rajagopal C, Garg VK (2006) Cadmium(II) uptake from aqueous solution by adsorption onto carbon aerogel using a response surface methodological approach. Ind Eng Chem Res 45:6531

Guo ZX, Cai Q, Yang Z (2005) Determination of glyphosate and phosphate in water by ion chromatography-inductively coupled plasma mass spectrometry detection. J Chromatogr A 1100:160-167

Guo D, Muhammad N, Lou C, Shou D, Zhu Y (2019) Synthesis of dendrimer functionalized adsorbents for rapid removal of glyphosate from aqueous solution. New J Chem 43(1):121-129

Hameed BH, Krishni RR, Sata SA (2009) A novel agricultural waste adsorbent for the removal of cationic dye from aqueous solutions. J Hazard Mater 162:305-311

Harrington EC (1965) The desirability function. Ind Qual Control 21:494-498

He X, Wu Z, Xue Y, Gao Z, Yang X (2019) Fabrication of interlayer $\beta-\mathrm{CD} / \mathrm{g}-\mathrm{C}_{3} \mathrm{~N}_{4} @ \mathrm{MoS}_{2}$ for highly enhanced photodegradation of glyphosate under simulated sunlight irradiation. RSC Adv 9(8):4635-4643

Herath I, Kumarathilaka P, Navaratne A, Rajakaruna N, Vithanage M (2015) Immobilization and phytotoxicity reduction of heavy metals in serpentine soil using biochar. J Soils Sediments 15:126-138

Herath I, Kumarathilaka P, Al-Wabel MI, Abduljabbar A, Ahmad M, Usman ARA, Vithanage M (2016) Mechanistic modeling of glyphosate interaction with rice husk derived engineered biochar. MicroporMesopor Mat 225:280-288. https://doi.org/10.1016/j. micromeso.2016.01.017

Ho YS, McKay G (1999) Pseudo-second order model for sorption processes. Process Biochem 34:451-465

Hosseini N, Toosi MR (2019) Removal of 2,4-D, glyphosate, trifluralin, and butachlor herbicides from water by polysulfone membranes mixed by graphene oxide/TiO2 nanocomposite: study of filtration and batch adsorption. J Environ Health Sci 17(1):247-258

Hu YS, Zhao YQ, Sorohan B (2011) Removal of glyphosate from aqueous environment by adsorption using water industrial residual. Desalination 271:150-156

Inama E, Etimb UJ, Akpabio EG, Umoren SA (2017) Process optimization for the application of carbon from plantain peels in dye abstraction. J Taibah Univ Sci 11:173-185

Jensen LC, Gan J, Baez M, Fuentes R, Escudey M (2009) Adsorption of glyphosate on variable-charge, volcanic ash derived soils. J Environ Qual 38:1449-1457

Jiang X, Ouyang Z, Zhang Z, Yang C, Li X, Dang Z, Wu P (2018) Mechanism of glyphosate removal by biochar supported nanozero-valent iron in aqueous solutions. Colloids Surf A Physicochem Eng Asp 547:64-72

Jiuhui QU (2008) Research progress of novel adsorption processes in water purification: a review. J Environ Sci 20:1-13

Kirby BJ (2010) Micro- and nanoscale fluid mechanics: transport in microfluidic devices. Cambridge University, Cambridge 
Lagergren S (1898) About the theory of so-called adsorption of soluble substances. Kungliga Suensk Vetenskapsakademiens Handlingar 241:1-39

Lancaster SH, Hollister EB, Senseman SA, Gentry TJ (2010) Effect of repeated glyphosate applications on soil microbial community composition and the mineralization of glyphosate. Pest Mang Sci 66:59-64

Li H, Huang G, An C, Hu J, Yang S (2013) Removal of tannin from aqueous solution by adsorption onto treated coal fly ash: kinetic, equilibrium, and thermodynamic studies. Ind Eeg Chem Res 52:15923-15931

Liu B, Dong L, Yu Q, Li X, Wu F, Tan Z, Luo S (2016) Thermodynamic study on the protonation reactions of glyphosate in aqueous solution: potentiometry, calorimetry and NMR spectroscopy. J Phys Chem B 120(9):2132-2137

Locke M, Zablotowicz R, Reddy K (2008) Integrating soil conservation practices and glyphosate-resistant crops: impacts on soil. Pest Manag Sci 64:457-469

Malik R, Ramteke DS, Wate SR (2007) Adsorption of malachite green on groundnut shell waste based powdered activated carbon. Waste Manag 27:1129-1138

Mayakaduwa SS, Kumarathilaka P, Herath I, Ahmad M, Al-Wabel M, Ok YS, Usman A, Abduljabbar A, Vithanage M (2016) Equilibrium and kinetic mechanisms of woody biochar on aqueous glyphosate removal. Chemosphere 144:2516-2521

Mondal NK, Roy A (2018) Potentiality of a fruit peel (banana peel) towards abatement of fluoride from synthetic and underground water samples collected from fluoride affected villages of Birbhum district. Appl Water Sci 8:90

Mondal NK, Basu S, Das B (2019a) Decontamination and optimization study of hexavalent chromium on modified chicken feather using response surface methodology. Appl Water Sci 9:50

Mondal NK, Ghosh P, Sen K, Mondal A, Debnath P (2019b) Efficacy of onion peel towards removal of nitrate from aqueous solution and field samples. Environ Nano Monitor Manag 11:100222

Montgomery DC (2001) Design and analysis of experiments, 5th edn. Wiley, New York

Mourabet M, Rhilassi AE, Boujaady HE, Bennani-Ziatni M, Hamri RE, Taitai A (2015) Removal of fluoride from aqueous solution by adsorption on hydroxyapatite (HAp) using response surface methodology. J Saudi Chem Soc 19:603-615

Nam SW, Choi DJ, Kimb SK, Her N, Zoh KD (2014) Adsorption characteristics of selected hydrophilic and hydrophobic micropollutants in water using activated carbon. J Hazard Mater 270:144-152

Poiger T, Buerge IJ, Bächli A, Müller MD, Balmer ME (2016) Occurrence of the herbicide glyphosate and its metabolite AMPA in surface waters in Switzerland determined with on-line solid phase extraction LC-MS/MS. Environ Sci Pollut R 24(2):1588-1596

Rajasulochana P, Preethy V (2016) Comparison on efficiency of various techniques in treatment of waste and sewage water: a comprehensive review. Resour Eff Technol 2:175-184

Richard S, Moslemi S, Sipahutar H, Benachour N, Seralini G (2005) Differential effects of glyphosate and roundup on human placental cells and aromatase. Environ Health Perspect 113:716-720

Roy TK, Mondal NK (2019) Potentiality of Eichhornia shoots ash towards removal of Congo red from aqueous solution: Isotherms, kinetics, thermodynamics and optimization studies. Groundwater Sustain Dev 9:100269
Sadafa S, Bhattia HN, Arifb M, Amina M, Nazarc F, Sultand M (2015) Box-Behnken design optimization for the removal of Direct Violet 51 dye from aqueous solution using lignocellulosic waste. Desalin Water Treat 56(9):2425-2437

Salleh MAM, Mahmoud DK, Abdul KWAW, Idris A (2011) Cationic and anionic dye adsorption by agricultural solid wastes: a comprehensive review. Desalination 280:1-13

Salman J, Abid F (2013) Preparation of mesoporous activated carbon from palm-date pits: optimization study on removal of bentazon, carbofuran, and 2, 4-D using response surface methodology. Water Sci Technol 68:1503-1511

Sen K, Mondal N, Chattoraj S, Datta JK (2017) Statistical optimization study of adsorption parameters for the removal of glyphosate on forest soil using the response surface methodology. Environ Earth Sci 76:22

Smidt E, Bohm K, Schwanninger M (2011) The application of FTIR spectroscopy. Int. Tech, Shanghai, pp 405-430

Sud D, Mahajan G, Kaur MP (2008) Agricultural waste material as potential adsorbent for sequestering heavy metal ions from aqueous solutions: a review. Bioresour Technol 99:6017-6027

Tan IAW, Hameed BH (2010) Adsorption isotherms, kinetics, thermodynamics and desorption of activated carbon derived from oil palm empty fruit bunch. J Appl Sci 10:2565-2571

Trivedi P, Delgado-Baquerizo M, Anderson IC, Singh BK (2016) Response of soil properties and microbial communities to agriculture: implications for primary productivity and soil health indicators. Front Plant Sci 7:990

Villamar-Ayala CA, Carrera-Cevallos JV, Vasquez-Medrano R, Espinoza-Montero PJ (2019) Fate, eco-toxicological characteristics, and treatment processes applied to water polluted with glyphosate: a critical review. Crit Rev Environ Sci Technol 49(16):1476-1514

Wachter R, Cordery A (1999) Response surface methodology modelling of diamond-like 1 carbon film deposition. Carbon $37: 1529-1537$

Wanyonyi WC, Onyari JM, Shiundu PM (2014) Adsorption of congo red dye from aqueous solutions using roots of Eichhornia crassipes: kinetic and equilibrium studies. Energy Procedia 50:862-869

Xu RK, Xiao SC, Yuan JH, Zhao AZ (2011) Adsorption of methyl violet from aqueous solutions by the biochars derived from crop residues. Bioresour Technol 102:10293-10298

Yakout SM, Sharaf El-Deen G (2016) Characterization of activated carbon prepared by phosphoric acid activation of olive stones. Arab J Chem 9:S1155-S1162

Yamaguchi NU, Bergamasco R, Hamoudi S (2016) Magnetic $\mathrm{MnFe}_{2} \mathrm{O}_{4}$-graphene hybrid composite for efficient removal of glyphosate from water. Chem Eng J 295:391-402

Yang Q, Wang J, Chen X, Yang W, Pei H, Hu N, Li Z, Suo Y, Lic T, Wang J (2018) The simultaneous detection and removal of organophosphorus pesticides by a novel $\mathrm{Zr}-\mathrm{MOF}$ based smart adsorbent. J Mater Chem 6:2184-2192

Zulkali MMD, Ahmad AL, Norulakmal NH (2006) Oryza sativa L. husk as heavy metal adsorbent: optimization with lead as model solution. Bioresour Technol 97:21

Publisher's Note Springer Nature remains neutral with regard to jurisdictional claims in published maps and institutional affiliations. 